\title{
Prostitution in Late Medieval Dubrovnik: Legislation, Practice and Prosecution
}

\author{
Gordan Ravančić \\ Croatian Institute of History, Croatia, gordan@isp.hr
}

\begin{abstract}
It is well known that the "world's oldest profession" was widespread across all of the Old World and that almost every pre-modern city had one or more brothels or "bathing houses", even though official public opinion and governments may not have encouraged this. In actuality, such establishments were a part of the local offer of amusements, especially in market towns and harbors which were frequently visited by outsiders. This contribution focuses one of these establishments - the official city brothel, its personnel and clientele using medieval Dubrovnik as a case study. Moreover, considering how even today public opinion is sharply divided on the issue of prostitution, investigating its medieval past also shows a wide range of conflicting attitudes.
\end{abstract}

Keywords: Prostitution; Dubrovnik; Middle Ages; sumptuary laws; sexuality. provided original work is properly cited and that this is not done for commercial purposes. Users may not remix, transform, or build upon the material and may not distribute the modified material (http://creativecommons.org/licenses/by-nc/4.0/) 


\title{
Prostitution in Late Medieval Dubrovnik: Legislation, Practice, and Prosecution*
}

\author{
Gordan Ravančić \\ Croatian Institute of History, Croatia
}

\section{Introduction}

When discussing prostitution in the Middle Ages, it is necessary to broach the question of contemporary sexuality. However, as this problem is broader than the issue at the center of this study (i.e. prostitution), it will be necessary to avoid speculation considering this broader framework. ${ }^{1}$ Many questions related to notions of sexuality, sex crime, sex violence and other situations of extramarital sex intersect with the sex trade in late medieval Dubrovnik.

Basically, prostitution can be defined as an exchange of sexual services for money or any other gift that can be considered as payment. $^{2}$ Thus, throughout the entire history of "the world's oldest profession" one can find a great number of various types of prostitutes: from ancient Babylonian temple harlots, to Rahab (the Biblical harlot

\footnotetext{
* This work has been supported in part by the Croatian Science Foundation under the project "Towns and Cities of the Croatian Middle Ages: Urban Elites and Urban Space," no. IP-2014-09-7235.

${ }^{1}$ More about sexuality in the Middle Ages see e.g.: Jacques Rossiaud, Amori venali. La prostituzione nell'Europa medievale (Bari - Rome: Laterza \& Figli Spa, 2013), esp. chapter "Sessualità e società del basso Medioevo", 61 and forward; Medieval Sexuality. A Casebook, April Harper and Caroline Proctor (eds.), (New York - London: Routledge, 2008); Constructing Medieval Sexuality, Karma Lochrie, Peggy McCracken, and James A. Schultz (eds.), (Minneapolis - London: University of Minnesota Press, 1997); James A. Brundage, Law, Sex, and Christian Society in Medieval Europe, (Chicago and London: The University of Chicago Press, 1987); Guido Ruggiero, The Boundaries of Eros. Sex Crime and Sexuality in Renaissance Venice (New York - Oxford: Oxford University Press, 1985).

${ }^{2}$ In this respect is quite interesting to note that such (sex) work usually paid more, even though it did not require any special education or skill. See: Lena Edlund and Evelyn Korn, “A Theory on Prostitution," Journal of Political Economy 110/1 (2002): 181-214.
} 
from Jericho), to medieval and pre-modern common women and courtesans, and of course to present-day prostitutes. ${ }^{3}$ Nevertheless, in medieval Dubrovnik it is possible to classify and reduce all of the existing variations into two basic groups: public prostitutes and clandestine prostitutes (concubines). ${ }^{4}$

Considering the case of concubines in Dubrovnik, one may come across the problem of whether or not they should be included in the same social group as public prostitutes. Namely, in late medieval Dubrovnik there were many illegitimate children with the surnames of great patricians. This points to the conclusion that many of those nobles had their own concubines (mostly female servants). Relations of that kind within a family were basically a "public secret". As such an affair could last for years and sometimes until the death of one of lovers, it is difficult to proclaim these female servants as prostitutes, especially if we know that their patrons often remembered them and their illegitimate children in wills and testaments. ${ }^{5}$ Therefore, this paper will only discuss cases that can be connected with prostitution as a

3 Regarding the classification of medieval prostitutes, see (along with the other literature) Amy K. Presser, "Medieval Prostitution" (unpublished essay, University of California, Santa Cruz, 1992), 2.

${ }^{4}$ About the latter, see Gordan Ravančić, "Ženska posluga u dobrostojećim obiteljima srednjovjekovnog Dubrovnika" [Female servants in wealthy families in medieval Dubrovnik], in: Dies Historiae 6: Žene kroz povijest, Matea Jalžečić and Petra Marinčić (eds.), (Zagreb: Hrvatski studiji Sveučilišta u Zagrebu, 2014), 69-82.

Regarding aforementioned distinction between "prostitutes" and "concubines" see e.g.: Ruth Mazo Karras, Common Women. Prostitution and Sexuality in Medieval England (New York - Oxford: Oxford University Press, 1996), 11.

5 Similar situations regarding concubines can also be traced among families of Italian patricians, as well as among wealthy non-noble families. In fact, concubinage was quite widespread and common throughout the entire medieval period in Europe. Reasons for this situation could be related to various factors from economic to social, and premedieval tradition also played an important role. Moreover, there was no formal prohibition of lay concubinage until the sixteenth century. See e.g.: Leah Lydia Otis, Prostitution in Medieval Society. The History of an Urban Institution in Languedoc (Chicago and London: The University of Chicago Press, 1985), 102, 107-108, 233 (endnote 49); James A. Brundage, Law, Sex and Christian Society in Medieval Europe (Chicago and London: The University of Chicago Press, 1987), 514-517, 548, 606; Gwenn Meredith, "Concubines", in: Women and Gender in Medieval Europe. An Encyclopedia, Margaret Schaus (ed.), (New York - London: Routledge, 2006), 156-158; Sandy Bardsley, Women's Roles in the Middle Ages (Westport, Conn. - London: Greenwood Press, 2007), 105. 
profession, that is (more or less) public prostitution and public prostitutes.

\section{Dubrovnik's prostitutes}

As Dubrovnik in the fourteenth and fifteenth centuries was a frequently visited harbor and a busy market, it is normal to assume that this city provided incoming sailors, merchants, travelers (as well as inhabitants of the city) with some kind of amusement. Aside from church relics and occasional festivities, there were also taverns. Sexual services both in and out of brothels were certainly included in this kind of offering.

Unfortunately, the archives in Dubrovnik do not have much in the way of surviving evidence for prostitutes and their activities, even though they would have undoubtedly had a significant presence in such a large city. Considering the amount of evidence, it is possible to propose a question: Why is the evidence so scarce? This question will be revisited later on in this paper. Still, in spite of this relative scarcity of relevant sources, the extant evidence can reveal some patterns and lead to certain conclusions.

The normative sources from Dubrovnik (Statutes, Ordinances of the Great Council, and other legal books) surprisingly do not pay much attention to this sphere of daily life. In the city statutes from 1272 all such problems (i.e. immoral behavior) should be solved within the family, meaning that the father or brothers of a woman or a girl who committed such a "crime" should punish her according their own wishes. ${ }^{6}$ Moreover, in the statute there are no regulations or restrictions for clothing worn by prostitutes; nor were they required to wear any distinctive marks (such as a special cord or belt) like in other European cities. ${ }^{7}$ Furthermore, in these "early" regulations of Dubrovnik (from

${ }^{6}$ Statut grada Dubrovnika [Statute of the city of Dubrovnik] (Dubrovnik: Historijski arhiv Dubrovnik, 1990), lib. 4 c. 72: Si vero bastarda ipsa non maritata devenerit meretrix vel malefica aut fuffiana, tam ipse pater quam filii sui legitimi potestatem babeant castagandi et percuciendi eandem, expellendi et eciam extra civitatem vendendi.

${ }^{7}$ Only one regulation considering the vestment of prostitutes exists, but this one dates from 1652 (Consilium Rogatorum, vol. 104, fol. 48-48'): ... de providendo et probibendo quod meretrices non possint vestire modo masculorum neque de nocte, sub poena standi ad publicam berlinam per spatium unius horae toties quoties, et illis, cum quibus inspectaefuerint sic vestitae, standi per sex menses continuos in carcere toties quoties... See: Risto Jeremić and Jorjo Tadić, Prilozi za 
the thirteenth and fourteenth centuries) there is not even a trace of regulations concerning where prostitutes should live or a circumscribed area within the city where the prostitutes could carry on their profession. ${ }^{8}$

On the other hand, statutes from other Dalmatian cities from the fourteenth century (e.g. the statutes of Split) contain such regulations. ${ }^{9}$ The probable reason why the statute of Dubrovnik does not contain such regulations is the fact that the commune in the thirteenth century was not at that point so distinctly socially divided, and therefore the authorities did not have a need to delineate social topography in the city. ${ }^{10}$ Similarly, the statute of Korčula (also from the thirteenth century) does not contain such regulations. In other parts of Europe, prostitution was controlled largely by city authorities, whether through sanctioned houses of prostitution or through criminal courts. ${ }^{11}$

In Dubrovnik, the first known regulation addressing the residence of prostitutes dates from 1409, where it is prescribed that public prostitutes should stay and perform their profession only in one particular part of the city (the outlined area marked with a shoe, heart and money on Figure 1). ${ }^{12}$ Other sources from Dubrovnik (primarily

istoriju zdravstvene kulture starog Dubrovnika [Contributions for the history of health in old Dubrovnik] vol. 3 (Belgrade: Centralni higijenski zavod, 1940), 122. On the other hand, in contemporary urban communities there are many examples of "marking" prostitutes by prescribing their clothes. See e.g.: Diane Wolfthal, "Picturing same-sex desire: the falconer and his lover in images by Petrus Christus and the housebook master," in Troubled Vision: Gender, Sexuality, and Sight in Medieval Text and Image, ed. Emma Campbell and Robert Mills (New York: Palgrave-MacMillan, 2004), 18; Edith Ennen, The Medieval Woman (Oxford UK - Cambridge USA: Basil Blackwell, 1989), 194-195; Ruth Mazo Karras, Comon Women. Prostitution and Sexuality in Medieval England (New York - Oxford: Oxford University Press, 1996), 20-22, 31, 33-34.

8 On relations between prostitutes and sumptuary regulations of clothing, see Presser, "Medieval prostitution", 18-21.

${ }^{9}$ E.g. Statut grada Splita [Statute of the city of Split] (Split: Književni krug, 1987), lib. 4 c. 39

10 The closing of the Great Council in Dubrovnik happened in the first half of the fourteenth century. The same process could be traced also in other Dalmatian cities.

11 Ruth Mazo Karras, "The Regulation of Sexuality in the Late Middle Ages: England and France," Speculum 86/4 (2011): 1027.

12 Reformationes, vol. 33, fol. 88: ... quod publice meretrices habitantes bic Ragusii debeant habitare et comorari a domo ser Marini de Zrieva usque ad maceriam hospitalis ser Marini de Bodacia per rugam versus mare usque ad media civitatis et in nullo alio loco in civitate Ragusii possint comorari; et quod dicte debeant se reducere ad dictum locum comorantes per totum presentem mensem februarii, sub 
records of criminal justice) prove that even before this regulation at least one brothel or a community of prostitutes existed at a place called Castelleto, ${ }^{13}$ most probably named after the part of the city where it was located. ${ }^{14}$ There is no evidence of any bathhouse in this period, ${ }^{15}$ possibly because the city is on the sea coast. Besides these prostitutes, the head of this community of common women was the "abbess of sinners" (abbatissa di peccatrices). There were also many freelance prostitutes who performed in their own homes or in houses provided by their procuress.

In the same quarter of the city as the brothel, there were also a few taverns. ${ }^{16}$ Although it is very probable, it is difficult to say whether prostitutes frequented these taverns. ${ }^{17}$ In the criminal records from the

poena eis et cuilibet ipsarum dando ad beneplacitum regiminis, si contrafactum fuerit per ipsas vel aliqua earum. See: Jeremić and Tadić, Prilozi za istoriju zdravstvene kulture, 119.

13 In fact, from the information gathered from the extant sources it is not clear whether this was a brothel or a community/association of local prostitutes who dwelled and worked in this area. E.g. Lamenta de intus, s. 51, vol. 1, fol. 153'; Dušanka DinićKnežević, Položaj žene u Dubrovniku u XIII $i$ XIV veku [Position of woman in Dubrovnik in the $13^{\text {th }}$ and $14^{\text {th }}$ centuries], Odeljenje istorijskih nauka 2 (Belgrade: Srpska akademija nauka i umetnosti, 1974), 141; Jurica Bačić, "Donne pubbliche u srednjovjekovnom Dubrovniku" [Donne pubbliche in medieval Dubrovnik] Acta bistorica medicinae, stomatologiae, pharmaciae, veterinae 16/2 (1976): 66.

${ }^{14}$ Considering the name of this brothel/community, the similarity with Venice is more than interesting, for the Venetian "red-light district" was also named castelleto. See: Jacques Rossiaud, Medieval Prostitution (Oxford and Cambridge: Blackwell, 1995), 59. Unfortunately, due to the scarcity of the relevant preserved the reasons for this similarity cannot be explained at present.

15 On the relationship between medieval prostitution and bath-houses, see together Amy K. Presser, "The Art of Bathing: Images of Bathmaids, Their Cohorts, and Their Clients" (MA thesis, Boston University, 1995), passim.

${ }^{16} \mathrm{By}$ the same token, we can also trace taverns in other parts of the city. E. g. Libri de maleficiis, 50-1, vol. 2, fol. 94'; Lamenta de intus, 51, vol. 2, fol. 120 (State Archives in Dubrovnik).

17 On the other hand, similar research in other European cities revealed that prostitutes were quite common in local taverns. See e.g.: Karras, Common Women, 15, 24-25, 46, 71; Ennen, The Medieval Woman, 196; April Harper, "The Food of Love," in Medieval Sexuality. A Casebook, ed. April Harper and Caroline Proctor (New York and London: Routledge, 2008), 82; A. Lynn Martin, "The Role of Drinking in the Male Construction of Unruly Women," in Medieval Sexuality. A Casebook, ed. April Harper and Caroline Proctor (New York and London: Routledge, 2008), 103. Moreover, many female tavern keepers had unsavory reputations for selling both their drinks and their bodies. See: A. Lynn Martin, Alcohol, Sex, and Gender in Late Medieval and Early Modern Europe, (Basingstoke -New York: Palgrave, 2001), 72. 
fourteenth and the first half of fifteenth century there were only just a few women mentioned as tavern guests. ${ }^{18}$ However, it is very probable that women (and prostitutes among them) avoided conflict situations, making it incredibly difficult to trace them in taverns. Besides this, the tavern was a public, and often very rough, place; "respectable" women were not to be seen there because the proper environment for a medieval woman was her family, in private. ${ }^{19}$

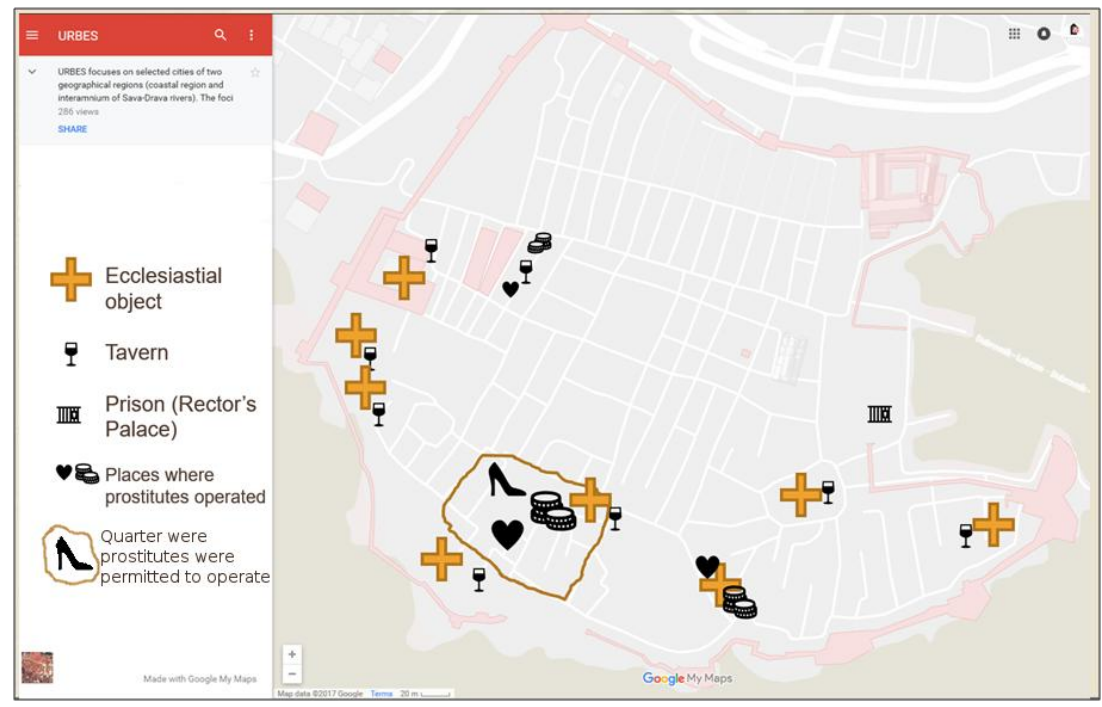

Fig. 1. Position of Castelletto, sites of prostitionand placement of some taverns in Dubrovnik

18 Mostly, women who are mentioned in the sources as visitors of a tavern usually went there just to buy wine for home usage. On their way to the tavern (usually in front of it) they sometimes were abused by the men who sat there and talked over a glass or bottle of wine. E.g. Libri de maleficiis, 50-1, vol. 2, fol. 18', 94', 183, 213'; Ibid, vol. 6, fol. 184'187.

${ }^{19}$ See e.g.: Ennen, The Medieval Woman, 8, 88; A History of Women in the West vol. 2, ed. Christiane Klapisch-Zuber (Cambridge and London: Harvard University Press, 1995), passim; David Nicholas, The Domestic Life of a Medieval City: women, children and the family in 14th-century Ghent, (London: Lincoln, 1985), passim. An example of what can happen when a woman enters a tavern can be seen in the case of Elsa Stecklin in Michael M. Hammer, "Prostitution in urban brothels in late medieval Austria", same volume. Still, one has to note that in medieval towns and cities non-noble women could also learn and practice a craft and even join a guild. Ennen, The Medieval Woman, $150 \mathrm{ff}$. 
On the other hand, men often combined drinking with other carnal pleasures which could be obtained from prostitutes. Many such adventures did not have a criminal ending, and therefore the evidence about these activities does not survive in the records of criminal justice. However, one incident shows how men amused themselves in this "red-light district" of late medieval Dubrovnik. On the evening of March 22, 1408, Johannes trumpeter (Johannes tubator) went to the Castelletto for a drink with some friends. Along the way they met a prostitute who offered them her services. Initially, the friends considered this offer but soon after two Slavs (Sclawi) arrived; they did not let the group to enter the rooms of the prostitute, even though she said that Johannes' friends had already paid her. Soon after, a fight broke out in which Johannes was hurt so badly that afterwards he had to give his testimony lying in bed at home. ${ }^{20}$ Surprisingly, the prostitute was not asked to give her testimony, nor was she prosecuted. This discloses that prostitutes were quite openly visited, not only by foreigners but also by the inhabitants of the city. It is also worth asking: who were these two Slavs? Were they procurers or just other customers who wanted this particular prostitute for themselves? Unfortunately, it is impossible to answer this question since the source does not tell us anything specific. Still, this case supports the idea that Dubrovnik prostitutes operated in the vicinity of local taverns.

By the same token, the aforementioned lack of extant sources does not provide the possibility of estimating the number of active public prostitutes in this period. It is not even possible to tell anything about their age or identify. It is possible to explain this scarcity by the fact that in the councils' records there is no trace of any financial support to such an institution, like in the case of some Italian cities (e.g. Florence). ${ }^{21}$ Still, it is intriguing that authorities in Dubrovnik did not seize the opportunity to profit from a lucrative business like running a brothel, nor did they officially tax this kind of business. Moreover, the existence of the aforementioned abbatissa suggests a certain institutional recognition. Yet, given the fact that the Dubrovnik city authorities

${ }^{20}$ Libri de maleficiis, 50-1, vol. 2, fol. 107'.

${ }^{21}$ Bronisław Geremek, The margins of society in late medieval Paris (Cambridge: Cambridge University Press, 1991), 211-241; Rossiaud, Medieval Prostitution, 59-60 and passim; James A. Brundage, Law, Sex and Christian Society (Chicago: University of Chicago Press, 1987), 522-523. 
often acted in accordance with moral modesty and Christian morality, it is probable that they did not want to take part in such an immoral and dishonest business (at least on paper).

On the other hand, evidence from the criminal records proves that prostitutes existed in the city and that they were not prosecuted because of their profession (at least not until the second half of the fifteenth century). In several cases, they were openly addressed to the court of justice as prostitutes (meretrices). ${ }^{22}$ Even in cases from the period before the second half of the fifteenth century in which a prostitute was sentenced, the reason for the accusation and the sentence was not because of her profession but rather because she disobeyed some regulations or violated some rector's orders which were not necessarily related to her profession. A good example of this is a case from 1431; during the Easter night, a prostitute entered the city jail probably in order to "entertain" jail guards or maybe even a prisoner. ${ }^{23}$ The next day she was found in the prisoner's cell and condemned almost immediately. Similarly, the prisoner and the guard who let her in were also punished. This undoubtedly proves that she was not sentenced because she was a prostitute, but because she had disobeyed the rector's order. Therefore, on the basis of this and other similar cases, we can assume that it is quite probable that the authorities in Dubrovnik unofficially tolerated prostitution, though they did not support it.

\section{Attitudes towards prostitution}

Even though prostitution was tolerated it does not mean that this profession was esteemed as a respectable or decent one. On the contrary, earning money by "selling of one's own flesh" for the pleasure of others was not viewed as a proper way of living, though it

\footnotetext{
22 E.g. Libri de maleficiis, 50-1, vol. 2, fol. 107'; Lamenta de intus, 51, vol. 1, fol. 153'.

${ }^{23}$ Libri de maleficiis, 50-1, vol. 6, fol. 142'. From the preserved criminal record it is not quite clear why and under which circumstances this prostitute entered the city jail. Namely, from the testimony of one of the jail guards it is clear that this prostitute was imprisoned (under unknown charges) two days before; and while being imprisoned she washed someone's hair (head). The next day she was released. The following evening, she returned with one of the jail guards, but obviously not to be imprisoned again; and the next morning the rector - during his regular visit of the city's jail - found her in one of the jail cells.
} 
was preferable to stealing or gambling. ${ }^{24}$ Moreover, the criminal records witness that one of the most common verbal insults was calling someone a meretrix (sometimes putana or curva) or, if it was man, calling him filius unius meretricis. ${ }^{25}$

It is now worth asking why authorities in Dubrovnik tolerated prostitution even if the women themselves had an unsavory reputation. As it turns out, the reason is actually quite simple and can be explained by daily experience. Namely, young men in medieval Dubrovnik (as in other European cities ${ }^{26}$ gathered in gangs that occasionally roamed across the city seeking to "find" and reinforce their masculinity. ${ }^{27} \mathrm{~A}$ number of cases disclose that very often they intended to prey on women who accidentally came across their way. ${ }^{28}$ Though it is difficult to ascertain with certainty how often this type of rape happened, the authorities realized that they had to do something. The solution was right in front of them and they seized the opportunity; as with many other cities in Europe, Dubrovnik accepted St. Augustine's doctrine and viewed prostitution as a lesser, though necessary evil which would prevent possible cases of rape and assault of women.

${ }^{24}$ Beno Kotruljević, O trgovini i savršenom trgovcu [About trade and the perfect merchant] translated into Croatian by Žarko Muljačić (Dubrovnik: Dubrovački trgovačko turistički sistem, 1989), 291; See also: Benedetto Cotrugli, Della mercatura et del mercante perfetto (Venice: n.p., 1573). There also exists an English edition of this book: B. Cotrugli, The Book of the Art of Trade, Carlo Carraro and Giovanni Favero (eds.), translated in English by John Francis Phillimore, (New York: Palgrave Macmillan, Springer Nature, 2017) which has not been consulted here.

25 E.g. Libri de maleficiis, vol. 4, fol. 252' (... putana dei pudari tute serasti in la camera et festi el tuouolar), 262 (curva rusciana); Libri de maleficiis, vol. 8, fol. 287' (... quod ipse est filius meretricis et quod eius sorores sun meretrices...); Ibid, vol. 9, fol. 97 (putana); Lamenta de intus, 51, vol. 1, fol. 181, 225; Ibid, vol. 2, fol. 218.

${ }^{26}$ For examples see: Rossiaud, Medieval Prostitution, 19-26 and passim; Leah Lydia Otis, Prostitution in Medieval Society. The History of an Urban Institution in Languedoc, (Chicago and London: The University of Chicago Press, 1985), 9-12; Brundage, Law, Sex and Christian Society, 522-526ff.

27 It was understood that, as medieval men were more emotional and temperamental than at present, they usually expressed their feelings in very quick-tempered manner. See: Johan Huizinga, The $W$ aning of the Middle Ages, passim. For the examples from medieval Dubrovnik see: Zdenka Janeković Römer, "Post tertiam capanam. Noćni život Dubrovnika u srednjem vijeku" [Night life of Dubrovnik in the Middle Ages], Anali Zavoda za povijesne znanosti HAZU u Dubrovniku 32 (1994): 7-14.

${ }^{28}$ E. g. Libri de maleficiis, 50-1, vol. 6, fol. 71'; Ibid, vol. 7, fol. 184'-187, 199'; Lamenta de intus, 51, vol. 1, 12'-13', 166', 203, 205; Ibid, vol. 3, fol. 15. 
However, it seems that by the second half of the fifteenth century (as it is previously indicated) the situation had changed. In 1456, we have the first known case where prostitutes were prosecuted. On 26 February 1456, the rector of the city, on the basis of anonymous denunciation, decided to expel six women because of "their dishonest life". ${ }^{29}$ Two of them probably were concubines of a nobleman (Raduana et Gliubiza staterunt cum ser Johanne de Goze), and two others (Cattarina relicta Goissavi mercatoris Stana cum duabus filiis) were likely forced into prostitution because of poverty. The latter two sentenced women who had lived with a tavern-keeper are especially interesting, for it raises the question as to whether this tavern-keeper was their procurer. This assumption leads us, again, to the aforementioned (but not proven in Dubrovnik) link between prostitution and the tavern. All of these sentenced women lived in the vicinity of the church of Saint Margaret (church with heart and money on the plan) and perhaps this was the reason why they were sentenced; they were not living in the prescribed part of the city. Similarly, at this time in places like the Languedoc, there was a significant growing opposition in lay public attitudes towards concubinage. ${ }^{30}$

Another case from 1464 reveals a little bit more. This time, the widow Polonia was sentenced to a year of expulsion from the city because she "corrupted many young men who frequented her place". 31 Similarly, in 1495 the rector expelled Miliza, who lived in the Via Larga, because of her "vicious life". 32 In the case of Miliza it can be assumed that she was sentenced because she also did not live in the prescribed

29 Consilium Minor: ... quod dominus rector debeat expelli facere de vicinia prope Sanctam Margaritam illas mulieres quas secundum relationem et informationem dictorum vicinorum habebitesse male fame et inhoneste vite, videlicet Cattarinam relictam Goissavi mercatoris Stana cum duabus filiis, videlicet Raduana et Gliubiza staterunt cum ser Johanne de Goze, et Stanula et Zivana stant in domo Radauni tabernarii. See: Jeremić and Tadić, Prilozi za istoriju zdravstvene kulture, 119.

30 Otis, Prostitution in Medeieval Society, 107-108.

31 Consilium Minor, vol. 16, fol. 161': ... de sententioando Poloniam relictam Giuraghi Marijich, quod debeat exulare per unum annum contiuum a civitate et jurisdictione nostra et hoc propeter pessimam informationem de ea babitam quod corrumpit et viciat plures juvenes in civitate nostra et ad domum suam divertitur et frequentatur qui in is a domo tenent et exercent malas artes. Ibid, 120.

32 Consilium Minor, vol. 23, fol. 167: ... de inrtomittendo Milizam que stat in domo Petri Cassellarii ad viam largam propter malam famam seu viciose vite. ... de inrtomittere Milizam ... et de tenendo eam ligatam ad carrum per unum diem et illam et die quando levabitur a carro debeat frustari per civitatem et deinde debeat bandiri et exulare per totam vitam suam a Ragusio et eius distructu. See: Ibid, 121. 
area of the city (money, heart and wine glass on the map) but also it is also important to pay attention to the explanations of the verdicts. According to these explanations (corruption of youth and vicious life), it seems that the attitude towards prostitution changed, begging the question: Why? What caused this shift?

Elsewhere in Europe, prostitution endured a decline during the period of the Renaissance and Reformation. ${ }^{33}$ As these persecutions of prostitutes in the sixteenth century are not the main subject of this article, I aim here to simplify the problem and reasons why it happened. One of the reasons was the emergence of syphilis and soon afterward medieval men realized the connection between the spreading of the disease and sexual intercourse. The next and perhaps more important reason was that the Catholic Church faced a great deal of criticism from Protestants due to the perceived two-faced morality, endangering its moral authority. The immediate reaction of the Catholic Church was the reorganization incapite et in membris, which also reflected their attitude towards prostitution, as before this the Church had disapproved of prostitution but tolerated it in practice. ${ }^{34}$ Such a practice of priests to frequent sex workers is visible even in the mid-fifteenth century Dubrovnik. ${ }^{35}$ These examples of "lusty" clerics reveal that this hypothetical shift in the attitude towards prostitution in late medieval Dubrovnik was not so radical, though Dubrovnik throughout the entire period was deeply influenced by and adherent to Catholic morality, ideology and practices.

However, there is a possible explanation for the change in this attitude. Since there is no possibility to investigate the official opinion of the church authorities in Dubrovnik in this period, ${ }^{36}$ it seems that

${ }_{33}$ Brundage, Law, Sex and Christian Society, 546ff; Otis, Prostitution in Medieval Society, 43, 89ff; Rossiaud, Medieval Prostitution, passim.

34 Istvàn Bejczy, "Tolerantia: A Medieval Concept," Journal of the History of Ideas 58/3 (1997): 371-372; James A. Brundage, “Allas! That evere love was synne: Sex and Medieval Canon Law," The Catholic Historical Review LXXII/1 (1986): 12; Frances and Joseph Gies, Women in the Middle Ages (New York: Harper \& Row, 1978), 56-58.

35 E. g. In 1464 priest Blaise (presbiter Blasius quondam Ratchi Dupetina) was expelled from the city because he frequently visited one woman during the night hours. See: Jeremić and Tadić, Prilozi za istoriju zdravstvene kulture, 119.

36 It would be very useful to consult the sermons from this period but, unfortunately, I was not able to analyze them since the Dominican library in Dubrovnik still is not open 
the only way to trace the origin of this change is to try to investigate public opinion considering sexuality in general. The didactic work of Benko Kotruljević (Benedetto Cotrugli), a successful merchant from Dubrovnik who lived in the first half of the fifteenth century, has been particularly revealing. In 1458, he wrote a book Della mercatura et del mercante perfetto in which he tried to advise future merchants how to succeed in trade. In his opinion, success in business is necessarily connected with the way of living. Therefore, he gives examples how to live an honest and successful life. Although he does not speak about prostitution directly, in his work one can trace a reflection of public opinion about sexual behavior and sexuality. Thus, according to Kotruljević, sexual intercourse can be dangerous for the human mind and life. He gives an example of a nobleman who died recently after his wife had died. Afterwards, physicians examined his corpse and found out that his brain disappeared; their conclusion was that this happened because the nobleman was too sexually active. ${ }^{37}$

Of course, such an attitude towards sexuality is not something new, for it is simply a reflection of traditional scholastic viewpoints from the thirteenth century. ${ }^{38}$ However, it is important to notice that in one didactic work from the mid-fifteenth century such an attitude still was prized, even though bodily pleasures and prostitution were tolerated. As noted before, similar changes in the viewpoints towards sexuality can be traced in some cities of contemporary Languedoc. Moreover, a number of humanists in fifteenth-century Florence voiced their disapproval of excessive lust or passion, which they considered to be inimical to the civic and patriotic spirit of young people, as well as harmful to the health and spirit of the individual. ${ }^{39}$ Thus, one can note that Kotruljevićs viewpoints represent not only public opinion in Dubrovnik, but also that of contemporary humanists elsewhere in Europe.

By the same token, we can find an interesting regulation from the same period. In 1474, authorities of Dubrovnik proclaimed an order

for public research. Similarly, in the Dubrovnik archbishopric's archives data from medieval period was lost during the big earthquake of 1667.

${ }^{37}$ Kotruljević, O trgovini, 365.

38 Brundage, Law, Sex and Christian Society, 425.

39 Otis, Prostitution in Medieval Society, 108. 
contra sodomitas. ${ }^{40}$ As it is stated in the explanation of this prescription, its purpose was to prevent the spread of a "new" sin. A later supplement from 1534 elaborated this regulation in more specific details, forbidding the gathering of male youths and organizing daily schools for them in order to draw their minds from sinful thoughts. ${ }^{41}$ Whether or not homosexuality actually appeared in Dubrovnik is unimportant; the city government in this period tried directly to regulate sexual behavior of inhabitants using that as a pretext.

To understand this regulation properly, as well as the supposed modification in attitude towards prostitutes, we have to remember that the entire fifteenth century was a period of Dubrovnik's flourishing and city's swift growth in both the economic and cultural spheres. Besides this, the authorities of Dubrovnik were constantly trying to legally control almost every segment of daily life; this growth caused fear that something could change, that the traditional way of life could be changed. By the same token, one also must not forget that this period is the time of a humanistic approach to the world, an approach that advocated moderation, modesty and rationalization as a way of living.

Consequently, by the end of the fourteenth century Dubrovnik authorities had already started to impose various sumptuary laws, even trying to control way the people dress. ${ }^{42}$ The peak of this sumptuary legalization was the sixteenth century, since Dubrovnik at that time endured various challenges and calamities: from terrible plague epidemics, permanent threats from the Ottomans, demographic changes, and constantly fluctuating economic growth and political alliances. ${ }^{43}$ Moreover, due to the Ottoman conquest of Bosnia in the mid-fifteenth century, Dubrovnik faced significant immigration of

${ }^{40}$ Liber croceus, ed. Branislav Nedeljković, Zbornik za istoriju, jezik I književnost s. 3 vol. 24 (Belgrade: Srpska akademija nauka i umetnosti, 1997), c. 72.

41 On this see: BarišaKrekić, "Abominandum Crimen, Kažnjavanje homoseksualaca u renesansnom Dubrovniku" [Abominandum Crimen, Punishment of homosexuals in Renaissance Dubrovnik] Dubrovački horizonti 28 (1988): 45-52.

42 Ani Adulmar and Katarina Nina Simončič, "Kultura odijevanja Dubrovnika u Zlatno doba" [Clothing culture in Dubrovnik's Golden age], TEDI International Interdisciplinary Journal of Young Scientists from the Faculty of Textile Technology 6 (2016): 28-39;

43 Regarding general history of Dubrovnik in this period see e.g.: Robin Harris, Dubrovnik. A History (London: SAQI, 2003); Bariša Krekić, Dubrovnik, Italy and the Balkans in the Late Middle Ages (London: Variorum Reprints, 1980); Radovan Samardžić, Veliki vek Dubrovnika [Great Epoch of Dubrovnk], (Belgrade: Prosveta, 1983). 
people from its hinterlands which caused social and demographic change, though unfortunately no statistical data related to this survives to present. ${ }^{44}$

Thus, examining all of these criminal charges against prostitutes and attitudes towards sexuality and sumptuary regulations within this broader context, it then becomes clearer why some prostitutes were persecuted in the mid-fifteenth century. It was not shift in the attitude towards prostitution that caused those persecutions, but the simple rationalization and attempt to preserve traditional norms of life in an urban society that was enduring a massive cultural and economic change. On the other hand, these regulations in Dubrovnik served as a prelude to more serious changes towards prostitution that would later occur in the sixteenth century.

\section{Conclusion}

Late medieval and renaissance Dubrovnik was a vivid and frequented harbor and important crossroad of various trade routes, but - at the same time - it was nonetheless a quite conservative Catholic community. In such a community, prostitutes and prostitution were tolerated at the margins of the society, like in many other medieval cities in the European West. Though primary sources (i.e. criminal records and legislative ordinances) mention prostitutes and their activities, the scarcity of the preserved relevant sources unfortunately does not allow researchers to reconstruct daily life and social networks of prostitutes in medieval Dubrovnik. Still, preserved sources reveal a change of general attitude towards prostitution in the second half of the fifteenth century, which does not seem to be related to the general change of the Catholic ethics incited by the Reformation. Namely, the analysis of the preserved criminal charges against prostitutes shows that these prosecutions of prostitutes in Dubrovnik should be viewed in a broader context of sumptuary legislation.

\footnotetext{
44 See e.g.: Stjepan Krivošić, Stanouništvo Dubrovnika I demografsk epromjene u prošlosti [Population of Dubrovnika and demographic changes in the past], (Dubrovnik: Zavod za povijesne znanosti JAZU u Dubrovniku, 1990).
} 


\section{References}

\section{Primary sources}

Acta Consilii Minoris, ser. 5, vol. 16. State Archives Dubrovnik. Acta Consilii Minoris, ser. 5, vol. 23. State Archives Dubrovnik. Acta Consilii Rogatorum, ser. 3, vol. 104. State Archives Dubrovnik. Cotrugli, Benedetto. Della mercaturaet del mercante perfetto. Venice: n.p., 1573.

Kotruljević, Beno. O trgovini i savršenom trgovcu [About trade and the perfect merchant]. Dubrovnik: Dubrovački trgovačko-turistički sistem, 1989.

Lamenta de intus, ser. 51, vol. 1. State Archives Dubrovnik.

Lamenta de intus, ser. 51, vol. 2. State Archives Dubrovnik.

Lamenta de intus, ser. 51, vol. 3. State Archives Dubrovnik.

Liber croceus. Zbornik za istoriju, jezik i književnost s. 3 vol. 24, ed.

Branislav Nedeljković. Belgrade: Srpska akademija nauka i umetnosti, 1997.

Libri de maleficiis, ser. 50-1, vol. 2. State Archives Dubrovnik. Libri de maleficiis, ser. 50-1, vol. 4. State Archives Dubrovnik. Libri de maleficiis, ser. 50-1, vol. 6. State Archives Dubrovnik. Libri de maleficiis, ser. 50-1, vol. 7. State Archives Dubrovnik. Libri de maleficiis, ser. 50-1, vol. 8. State Archives Dubrovnik. Libri de maleficiis, ser. 50-1, vol. 9. State Archives Dubrovnik. Reformationes, ser. 2, vol. 33. State Archives Dubrovnik.

Statut grada Dubrovnika [Statute of the city of Dubrovnik]. Dubrovnik:

Historijski arhiv Dubrovnik, 1990.

Statut grada Splita [Statute of the city of Split]. Split: Književni krug, 1987.

\section{Secondary sources}

Adulmar, Ani and Simončič, Katarina Nina. "Kultura odijevanja Dubrovnika u Zlatno doba" [Clothing culture in Dubrovnik's Golden age]. TEDI International Interdisciplinary Journal of Young Scientists from the Faculty of Textile Technology 6 (2016): 28-39.

Bačić, Jurica. "Donne pubbliche u srednjovjekovnom Dubrovniku" [Donne pubbliche in medieval Dubrovnik]. Acta historica medicinae, stomatologiae, pharmaciae, veterinae 16/2 (1976): 55-69. 
Bardsley, Sandy. Women's Roles in the Middle Ages. Westport, Conn. London: Greenwood Press, 2007.

Bejczy, Istvàn. "Tolerantia: A Medieval Concept." Journal of the History of Ideas 58/3 (1997): 365-384.

Brundage, James A. "Allas! That evere love was synne: Sex and Medieval Canon Law." The Catholic Historical Review LXXII/1 (1986): 1-13. . Law, Sex and Christian Society in Medieval Europe. Chicago and London: The University of Chicago Press, 1987.

Dinić-Knežević, Dušanka. Položaj žene u Dubrovniku u XIII i XIV veku [Position of woman in Dubrovnik in the $13^{\text {th }}$ and $14^{\text {th }}$ centuries]. Odeljenje istorijskih nauka 2. Belgrade: Srpska akademija nauka i umetnosti, 1974.

Edlund, Lena and Korn, Evelyn. "A Theory on Prostitution.” Journal of Political Economy 110/1 (2002): 181-214.

Ennen, Edith. The Medieval Woman. Oxford UK - Cambridge USA: Basil Blackwell, 1989.

Geremek, Bronisław. The margins of society in late medieval Paris.

Cambridge: Cambridge University Press, 1991.

Gies, Frances and Joseph Gies. Women in the Middle Ages. New York: Harper \& Row, 1978.

Harper, April and Caroline Proctor, ed. Medieval Sexuality. A Casebook. New York - London: Routledge, 2008.

Harper, April. "The Food of Love." In Medieval Sexuality. A Casebook, ed. April Harper and Caroline Proctor, 81-97. New York and London: Routledge, 2008.

Harris, Robin. Dubrovnik. A History. London: SAQI, 2003.

Huizinga, Johan. The Waning of the Middle Ages. London: Penguin, 1987. Janeković Römer, Zdenka. "Post tertiam capanam. Noćni život

Dubrovnika u srednjem vijeku" [Night life of Dubrovnik in the Middle Ages]. Anali Zavoda za povijesne znanosti HAZU u Dubrovniku 32 (1994): 7-14.

Jeremić, Risto and Tadić, Jorjo. Prilozi za istoriju zdravstvene kulture starog

Dubrovnika [Contributions for the history of health in old

Dubrovnik] vol. 3. Belgrade: Centralni higijenski zavod, 1940.

Karras, Ruth Mazo. "The Regulation of Sexuality in the Late Middle Ages: England and France.” Speculum 86/4 (2011): 1010-1039. . Common Women. Prostitution and Sexuality in Medieval England. New York - Oxford: Oxford University Press, 1996. 
Klapisch-Zuber, Christiane, ed. A History of Women in the West vol. 2. Cambridge and London: Harvard University Press, 1995.

Krekić, Bariša. "Abominandum Crimen, Kažnjavanje homoseksualaca u renesansnom Dubrovniku" [AbominandumCrimen, Punishment of homosexuals in Renaissance Dubrovnik]. Dubrovački horizonti 28 (1988): 45-52.

. Dubrovnik, Italy and the Balkans in the Late Middle Ages. London: Variorum Reprints, 1980.

Krivošić, Stjepan. Stanovnistvo Dubrovnika i demografske promjene u prošlosti [Population of Dubrovnik and demographic changes in the past]. Dubrovnik: Zavod za povijesne znanosti JAZU u Dubrovniku, 1990.

Lochrie, Karma, McCracken, Peggy, Schultz, James A., eds. Constructing Medieval Sexuality. Minneapolis - London: University of Minnesota Press, 1997.

Martin, A. Lynn. "The Role of Drinking in the Male Construction of Unruly Women.” In Medieval Sexuality. A Casebook, ed. April Harper and Caroline Proctor, 98-112. New York and London: Routledge, 2008.

Martin, A. Lynn. Alcohol, Sex, and Gender in Late Medieval and Early Modern Europe. Basingstoke -New York: Palgrave, 2001.

Meredith, Gwenn. "Concubines." In Women and Gender in Medieval Europe. An Encyclopedia, ed. Margaret Schaus, 156-158. New York London: Routledge, 2006.

Nicholas, David. The Domestic Life of a Medieval City: Women, Children and the Family in 14th-Century Ghent. London: Lincoln, 1985.

Otis, Leah Lydia. Prostitution in Medieval Society. The History of an Urban Institution in Languedoc. Chicago and London: The University of Chicago Press, 1985.

Presser, Amy K. “Medieval Prostitution,” unpublished essay. University of California, Santa Cruz, 1992.

. "The Art of Bathing: Images of Bathmaids, Their Cohorts, and Their Clients." MA thesis, Boston University, 1995.

Ravančić, Gordan. "Ženska posluga u dobrostojećim obiteljima srednjovjekovnog Dubrovnika" [Female servants in wealthy families in medieval Dubrovnik]. In Dies Historiae 6: Žene kroz.povijest, eds. Matea Jalžečić and Petra Marinčić, 69-82. Zagreb: Hrvatski studiji Sveučilišta u Zagrebu, 2014. 
Rossiaud, Jacques. Amori venali. La prostituzione nell'Europa medievale. Bari - Rome: Laterza \& Figli Spa, 2013. - Medieval Prostitution. Oxford and Cambridge: Blackwell, 1995. Ruggiero, Guido. The Boundaries of Eros. Sex Crime and Sexuality in Renaissance Venice. New York - Oxford: Oxford University Press, 1985.

Samardžić, Radovan. VelikivekDubrovnika [Great Epoch of Dubrovnk]. Belgrade: Prosveta, 1983.

Tošić, Đuro. Srednjovjekovna turobna svakodnevica [Medieval gloomy daily life]. Belgrade: Institute of History, 2012.

Wolfthal, Diane. "Picturing same-sex desire: the falconer and his lover in images by Petrus Christus and the housebook master." In Troubled Vision: Gender, Sexuality, and Sight in Medieval Text and Image, ed. Emma Campbell and Robert Mills, 17-46. New York: PalgraveMacMillan, 2004. 